\title{
Pengaruh Perilaku Cyber Crime Terhadap Pengguna Aplikasi E-Commerce
}

\author{
John Reimon Batmetan, Hensy Watung, Leyri Nayoan, Avandi E. Untu \\ Prodi Pendidikan Teknologi Informasi dan Komunikasi, Universitas Negeri Manado, Tondano. 95318 \\ john.reimon@gmail.com, hensywatung5@gmail.com, leyrinayoan07@gmail.com, \\ ebigielvandi@gmail.com
}

\begin{abstract}
ABSTRAK
Teknologi E-Commerce merupakan suatu mekanisme bisnis yang bekerja secara elektronik dengan memfokuskan kepada transaksi bisnis secara online dan memiliki kesempatan untuk membangun hubungan yang lebih manusiawi dan memiliki personalisasi dengan pelanggan tanpa bergantung kepada ruang dan waktu. Tujuan dalam penelitian ini adalah untuk mengetahui sejauh mana, Pengaruh perilaku Cyber Crime terhadap pengguna aplikasi e-commerce yang mempengaruhi tingkat kepercayaan pengguna pelayanan transaksi E- Commerce. Data yang digunakan dalam penelitian ini adalah data primer, Metode analisis data yang digunakan adalah kuantitatif dengan menggunakan skala likert, Populasi dalam penelitian ini adalah sebanyak 30 responden sebagai sampel penelitian, dengan menggunakkan google form, Hasil penelitian berdasarkan analisis menunjukkan pengguna e-commerce menanggung banyak resiko di tambah dengan tingkat kepercayaan pengguna E- Commerce, menjadikan perilaku Cybercrime masih sangat sulit di antisipasi oleh pengguna pelayanan transaksi E- Commerce, berpengaruh secara Negatif dan signifikan
\end{abstract}

Kata kunci : Cyber Crime, E-Commerce, Pengguna Aplikasi,

\section{PENDAHULUAN}

Kemajuan dan perkembangan teknologi informasi sekarang ini merupakan salah satu acuan dalam menilai sukses tidaknya suatu bentuk perilaku manusia modern pada hampir semua bidang kehidupan [1]. Berkenaan dengan kemajuan dan perkembangan kebutuhan masayarakat tersebut, tentunya tidak lepas dari pembangunan teknologi informasi melalui internet (Interconnetion Network). Penggunaan internet untuk aktivitas transaksi bisnis dikenal dengan istilah Electronic Commerce (E-Commerce). E-Commerce dapat terjadi antara organisasi bisnis dengan konsumen, meliputi penggunaan Internet dan World Wide Web untuk penjualan produk dan pelayanan untuk konsumen. Teknologi E-Commerce merupakan suatu mekanisme bisnis yang bekerja secara elektronik dengan memfokuskan kepada transaksi bisnis secara online dan memiliki kesempatan untuk membangun hubungan yang lebih manusiawi dan memiliki personalisasi dengan pelanggan tanpa bergantung kepada ruang dan waktu [2].

Menurut Jelassi, Tawfik, Enders, Albrecht (2008, p.4) E-Commerce lebih spesifik daripada EBusiness dan dianggap menjadi hal yang paling akhir. Teori E-Business dan M-Commerce (Mobile 
Commerce). Teknologi E-Commerce merupakan suatu mekanisme bisnis yang bekerja secara elektronik dengan memfokuskan kepada transaksi bisnis secara online dan memiliki kesempatan untuk membangun hubungan yanglebih manusiawi dan memiliki personalisasi dengan pelanggan tanpa bergantung kepada ruang dan waktu [3].

E-Commerce itu sendiri berkaitan dengan fasilitas transaksi, penjualan produk dan layanan online melalui internet atau jaringan telekomunikasi lainnya. E-Commerce merupakan perdagangan elektronik yang menampilkan barang atau jasa yang dijualnya secara digital. E-Commerce meliputi semua langkah-langkah perdagangan seperti : pemasaran online, pemesanan online, pembayaran online, barang dan jasa secara digital dan distribusi online. Aplikasi pada E-Commerce berorientasi pada kegiatan eksternal yang terdapat 2 sisi yaitu : Buy-Side : Kegiatan atau proses pembelian kepada para pemasok atau suppliers. Sell-Side : Kegiatan atau proses penjualan kepada para pelanggan atau para resellers [4].

Bentuk-Bentuk Tipe E-Commerce menurut O'Brien (2005, p.384) adalah sebagai berikut :

\section{1) Business-to-Consumer (B2C)}

B2C ini menjelaskan perusahaan harus mengembangkan pasar elektronik yang menarik untuk menjual berbagai produk dan jasa ke para pelanggan. Contohnya banyak perusahaan menawarkan situs web E-Commerce yang menyediakan pajangan virtual dan katalog multimedia, pemrosesan pesanan interaktif, sistem pembayaran yang aman dan dukungan pelanggan online.

2) Business-to-Business (B2B)

B2B ini melibatkan pasar E-Business dan hubungan pasar langsung antar perusahaan.
Contohnya banyak perusahaan menawarkan situs web yang aman berisi katalok E-Commerce melalui internet atau ekstranet untuk para pelanggan dari perusahaan dan para pemasok.

3) Consumer-to-Consumer (C2C)

$\mathrm{C} 2 \mathrm{C}$ ini menjelaskan tentang keberhasilan besar dari lelang online seperti amazon, eBay, olx, KaskusFJB,dll yang merupakan tempat para pelanggan dan juga perusahaan dapat membeli serta menjual ke satu sama lain dalam proses situs web lelang, menjadikan $\mathrm{C} 2 \mathrm{C}$ sebuah strategis bisnis E-Commerce yang penting.

Penelitian ini bertujuan untuk Mengetahui Pengaruh Perilaku Cyber Crime terhadap pengguna aplikasi E- Commerce. Kuesioner yang akan digunakan adalah Use Questionaire yang memiliki beberapa aspek menurut efisiensi, efektivitas dan kepuasan. Kuesioner ini dibuat dalam bentuk skor lima poin dengan memakai model skala likert .

\section{METODE PENELITIAN :}

\section{Populasi dan Sampling}

Penelitian yang memiliki standar - standar tertentu, sesuai dengan tujuan penelitian, Responden yang di libatkan dalam penelitian ini adalah 30 Responden, dari suatu populasi yaitu, Guru, ASN, Karyawan dan Mahasiswa.

\section{Teknik Pengumpulan Data}

Data primer: diperoleh dengan penyebaran kuesioner dengan melalui google formulir untuk memperoleh data, dan dalam penelitian ini menggunakan skala Likert. Skala Likert adalah suatu skala psikometrik yang umum digunakan dalam angket dan merupakan skala yang paling banyak digunakan dalam riset berupa survey. Saat menanggapi pertanyaan dalam skala Likert, 
Responden menentukan tingkat persetujuan mereka mereke terhadap suatu pernyataan dengan memilih salah satu dari pilihan yang tersedia. Disediakan 5(lima) pilihan dengan format seperti : 1 = Sangat Tidak Setuju, 2 =.Tidak Setuju, 3 = Ragu - Ragu, 4 = Setuju, 5 = Sangat Setuju

Tabel. 1 Bobot Nilai

\begin{tabular}{llllll}
\hline PK & STS & TS & RR & S & SS \\
\hline 1 & 2 & 3 & 4 & 5 \\
\hline
\end{tabular}

Untuk mendapatkan data yang bersifat ordinal dan di beri skor sebagai berikut :

Keterangan

PK : Pertanyaan

STS : Sangat Tidak Setuju

TS : Tidak Setuju

RR : Ragu - Ragu

$S \quad:$ Setuju

SS : Sangat Setuju

Pada penelitian ini, langkah awal yang dilakukan adalah dengan mengidentifikasi masalah, selanjutnya dilakukan studi awal/studi pustaka terkait dengan Pengaruh Cybercrime terhadap pengguna aplikasi E-Commerce.

\section{HASIL DAN PEMBAHASAN}

Dalam penelitian ini, peneliti membagikan kuesioner kepada guru, ASN, Karyawan dan mahasiswa yang berisi 11 pertanyaan yang sudah mewakili aspek penilaian dengan menggunakan media google forms. Pengguna mengisi kuesioner yang sudah dibagikan berdasarkan pengalamannya pada saat menggunakan transaksi E-Commerce. Setiap pertanyaan dari kuesioner tersebut memiliki tujuan untuk mengetahui pengaruh cyber crime terhadapan aplikasi ECommerce, yang selanjutnya akan di nilai menggunakan skala Likert. Dari kuesioner yang telah diberikan kepada responden, data dianalisa menggunakan model skala likert.

\section{Rumus Index $\%=$ Total Skor $/$ Y x 100}

$\mathrm{Y}=$ Skor tertinggi likert $\mathrm{x}$ jumlah responden (Angka Tertinggi 5) "Perhatikan Bobot Nilai"

$\mathrm{X}=$ Skor terendah likert $\mathrm{x}$ jumlah responden (Angka Terendah 1) "Perhatikan Bobot Nilai"

Tabel. 2 Presentase Nilai

\begin{tabular}{ll}
\hline Jawaban & Keterangan \\
\hline $0 \%-19,99 \%$ & Sangat Tidak Setuju \\
\hline $20 \%-39,99 \%$ & Tidak Setuju \\
\hline $40 \%-59,99 \%$ & Ragu - Ragu \\
\hline $60 \%-79,99 \%$ & Setuju \\
\hline $80 \%-100 \%$ & Sangat Setuju \\
\hline
\end{tabular}

Jumlah skor tertinggi untuk item SANGAT SETUJU ialah $5 \times 30=150$, sedangkan item SANGAT TIDAK SETUJU ialah $1 \times 30=30$. Jadi, jika total skor responden di peroleh angka 150, maka penilaian interpretasi responden terhadap Sistem operasi Android tersebut adalah hasil nilai yang dihasilkan dengan menggunakan rumus Index $\%$. Setelah penyebaran kuesioner yang diberikan kepada 30 responden, makaselanjutnya dilakukan rekap terhadap hasil kuesioner yang diperoleh.

Tabel 3. Rekap Nilai

\begin{tabular}{llll}
\hline No & \multicolumn{1}{c}{ Pernyataan } & $\begin{array}{c}\text { Persent } \\
\text { ase }\end{array}$ & Ket \\
\hline 1. & $\begin{array}{l}\text { Melakukan Transaksi E } \\
\text { Commerce }\end{array}$ & $78 \%$ \\
\hline 2. & $\begin{array}{l}\text { E-Commerce mempermudah } \\
\text { komunikasi antara produsen } \\
\text { dan konsumen }\end{array}$ & \\
\hline
\end{tabular}




\begin{tabular}{|c|c|c|}
\hline 3. & $\begin{array}{l}\text { E- Commerce mempemudah } \\
\text { promosi barang dan jasa }\end{array}$ & $81,3 \%$ \\
\hline 4. & $\begin{array}{l}\text { Proses E- Commerce lebih } \\
\text { mudah dilakukan untuk } \\
\text { menjual atau membeli barang }\end{array}$ & $81,3 \%$ \\
\hline 5. & $\begin{array}{l}\text { Proses E- Commerce lebih } \\
\text { mudah untuk melakukan } \\
\text { pembayaran }\end{array}$ & $74,6 \%$ \\
\hline 6. & $\begin{array}{lll}\text { Transaksi E- } & \text { Commerce } \\
\text { Aman Untuk } & \text { melakukan } \\
\text { pembayaran } & \\
\end{array}$ & $64 \%$ \\
\hline 7. & $\begin{array}{l}\text { Sering terjadi } \quad \text { Fraud } \\
\text { Penipuan Secara Online }\end{array}$ & $80 \%$ \\
\hline 8. & $\begin{array}{l}\text { Saat Pembelian dan Transfer } \\
\text { Uang, tapi barang tidak sesuai } \\
\text { / barang tidak sampai }\end{array}$ & $66,6 \%$ \\
\hline 9. & $\begin{array}{l}\text { Terjadinya kejahatan seperti } \\
\text { carding atau seseorang } \\
\text { menggunakan kartu kredit } \\
\text { orang lain untuk melakukan } \\
\text { transaksi Online }\end{array}$ & $65,3 \%$ \\
\hline 10. & $\begin{array}{l}\text { Kejahatan terjadi seperti } \\
\text { penyebaran virus terhadap } \\
\text { system atau Aplikasi E- } \\
\text { Commerce }\end{array}$ & $71,3 \%$ \\
\hline 11. & $\begin{array}{l}\text { Undang - Undang tentang } \\
\text { Teknologi Informasi }\end{array}$ & $88,8 \%$ \\
\hline
\end{tabular}

Pada table diatas menunjukan nilai tiap butir pertanyaan yang diajukan. Dapat dilihat bahwa untuk kemudahan melakukan transaksi ECommerce, memiliki presentase nilai $78 \%$ dapat diartikan bahwa E-Commerce dapat dengan mudah dilakukan. Disesuaikan dengan table, data dikatakan bahwa Pengaruh Cybercrime terhadap pengguna aplikasi E-Commerce, Hal ini ditunjukkan dengan berbagai Faktor:

Nilai Presentase "Saat Pembelian dan Transfer Uang, tapi barang tidak sesuai / barang tidak sampai, 66,6 \%, Menunjukkan bahwa Risiko Finansial sangat besar, yaitu kemungkinan kerugian keuangan dan Risiko Waktu, yaitu kemungkinan merasa rugi waktu karena proses pembelian online, serta Risiko Kinerja, yaitu kemungkinan produk atau layanan tidak sesuai dengan yang diharapkan. "Sering terjadi Fraud / Penipuan Secara Online" 80 \%, Menunjukan bahwa Cyber Crime sangat mempengaruhi pengguna, dan
"Kejahatan terjadi seperti penyebaran virus terhadap system atau Aplikasi E- Commerce" 71,3 $\%$, membuat kerugian terhadap system.

Nilai Presentase. "Proses E- Commerce lebih mudah untuk melakukan pembayaran" $74,6 \%$ dan "Proses E- Commerce lebih mudah dilakukan untuk menjual atau membeli barang" $81,3 \%$, menunjukkan bahwa Risiko Fisik, yaitu kemungkinan kerugian secara fisik masih kurang.

Nilai Presentase"E-Commerce mempermudah komunikasi antara produsen dan konsumen" 76,6\% menunjukan Risiko Psikologis, yaitu kemungkinan merasa nyaman secara psikologis merasa nyaman karena bertemu dengan penjual, menjadi lebih dekat dengan berbagai fasilitas komunikasi.

Nilai Presentase“Terjadinya kejahatan seperti carding atau seseorang menggunakan kartu kredit orang lain untuk melakukan transaksi Online" $65,3 \%$, menunjukkan bahwa Faktor Keamanan Privacy, yaitu kemungkinan kerugian karena penyalah gunaan informasi personal oleh seseorang yang tidak bertanggung jawab, serta "Undang - Undang tentang Teknologi Informasi" $88,8 \%$ yang menunjukkan bahwa setiap pengguna memerlukkan perlindungan secara hokum yang jelas dan tegas untuk menindak lanjuti kejahatan dalam transaksi E- Commerce.

\section{KESIMPULAN}

Sistem transaksi E-Commerce yang digunakan oleh Pengguna / pembeli untuk mendapatkan barang yang diinginkan harus menanggung banyak resiko di tambah dengan tingkat kepercayaan pengguna E- Commerce, menjadikan perilaku Cybercrime masih sangat sulit di antisipasi oleh pengguna pelayanan transaksi E-Commerce. Kendala yang dihadapi dalam implementasi e- 
commerce adalah minimnya sumber daya manusia yang memahami dalam bidang penggunaan ecommerce sehingga belum dapat digunakan secara maksimal, serta masih banyak pembeli yang masih kurang percaya akan tingkat keamanan belanja online / E-Commerce dan susah merubah kebiasaan untuk bertransaksi secara online.

\section{DAFTAR PUSTAKA}

[1] S. M. Maulana, H. Susilo and R. , Implementasi E-Commerce Sebagai Media Penjualan Online, Malang, 2006.

[2] E. A. Pratama, Optimalisasi Cyberlaw Untuk Penanganan Cybercrime Pada Ecommerce, Purwokerto, 2013.

[3] S. Kosasi, Perancangan Sistem E-Commerce Untuk Memperluas Pasar, Pontianak, 2015.

[4] Y. Rahmawati, Pengaruh Cybercrime Pada Ecommerce.

[5] J. R. Batmetan Suyoto, J. D. C. L. Suares, "An Empirical Investigation on Customer Behavior to Adopt Mobile Commerce among the $Y$ Generation in Indonesia", Sriwijaya International Conference On Engineering, Science \& Technology [SICEST 2016], 2016

[6] J.R. Batmetan, "Algoritma Ant Colony Optimization (ACO) untuk Pemilihan Jalur Tercepat Evakuasi Bencana Gunung Lokon Sulawesi Utara", Jurnal Teknologi InformasiAITI, 2016, vol.13, no.2, pp 31-48

[7] L. Madeso, D. R. Kabo, J. R. Batmetan, " Rancang Bangun Sistem Pakar Penentuan Status Gizi Pada Balita Menggunakan Metode Forward Chainning", E-Jurnal UNSRIT, vol.2

[8] J. R. Batmetan, V. R. Palilingan, " Higher Education Students' Behaviour to Adopt Mobile Learning", IOP Conference Series: Materials Science and Engineering, 2018, vol. 306, Issue 1, pp. 012110 (2018)
[9] V. R. Palilingan, J. R. Batmetan, " Incident Management in Academic Information System using ITIL Framework", IOP Conference Series: Materials Science and Engineering, 2018, vol. 306, Issue 1, pp. 012110 (2018)

[10] J. R. Batmetan, A. J. Santoso, Pranowo, " A Multiple-Objective Ant Colony Algorithm for Optimizing Disaster Relief Logistics", Advanced Science Letters, 2017, vol.23, no.3, pp. 2344-2347

[11] M. L. Tompodung, F. Supit, J. R. Batmetan, " Rancang Bangun Aplikasi Sensus Penduduk Berbasis Android", Buletin Sariputra, 2017, vol.7, pp. 57-61

[12] J. R. Batmetan, " Optimasi Strategi Smart Environment Dalam Mitigasi Bencana Menggunakan Multi-Objective Aco (Mo-Aco) Algorithm", Pasca Sarjana Magister Teknik Informatika Universitas Atma Jaya Yogyakarta, 2016 